\title{
A Genome-Wide Association Study of spontaneous preterm
}

\section{birth in a European population [version 1; peer review: 2}

\section{approved with reservations]}

\author{
Wilfred Wu¹, Erin A S Clark², Tracy A Manuck², M Sean Esplin², Michael W Varner2, \\ Lynn B Jorde ${ }^{1}$
}

${ }^{1}$ Department of Human Genetics, University of Utah School of Medicine, Salt Lake City, UT, 84112, USA

${ }^{2}$ Department of Obstetrics and Gynecology, University of Utah School of Medicine, Salt Lake City, UT, 84112, USA

V1 First published: 25 Nov 2013, 2:255
https://doi.org/10.12688/f1000research.2-255.v1
Latest published: 25 Nov 2013, 2:255

https://doi.org/10.12688/f1000research.2-255.v1

\section{Open Peer Review}

\begin{tabular}{ccc} 
Approval Status & $?$ ? \\
& 1 & 2 \\
\hline version 1 & $?$ & $?$ \\
25 Nov 2013 & view & view \\
\hline
\end{tabular}

1. Mohamad Saad, University of Washington, Seattle, WA, USA

2. David Olson, University of Alberta, Edmonton, AB, Canada

Scott Williams, Dartmouth College, Hanover, USA

Any reports and responses or comments on the article can be found at the end of the article. 
Corresponding author: Lynn B Jorde (Ibj@genetics.utah.edu)

Competing interests: No competing interests were disclosed.

Grant information: EASC is supported by National Institutes of Health, National Institute of Child Health and Human Development (K23HD061910).

The funders had no role in study design, data collection and analysis, decision to publish, or preparation of the manuscript.

Copyright: $\odot 2013$ Wu W et al. This is an open access article distributed under the terms of the Creative Commons Attribution License, which permits unrestricted use, distribution, and reproduction in any medium, provided the original work is properly cited. Data associated with the article are available under the terms of the Creative Commons Zero "No rights reserved" data waiver (CC0 1.0 Public domain dedication).

How to cite this article: Wu W, Clark EAS, Manuck TA et al. A Genome-Wide Association Study of spontaneous preterm birth in a European population [version 1; peer review: 2 approved with reservations] F1000Research 2013, 2:255

https://doi.org/10.12688/f1000research.2-255.v1

First published: 25 Nov 2013, 2:255 https://doi.org/10.12688/f1000research.2-255.v1 


\section{Introduction}

Definition and significance of preterm birth

Preterm birth (PTB), defined as birth prior to 37 completed weeks' gestation, is a major public health problem that affects more than $10 \%$ of all births worldwide ${ }^{1,2}$. Globally, an estimated 15 million babies are born premature each year ${ }^{1,2}$. Despite substantial public health efforts over the past several decades, the U.S. PTB rate remained at $11.72 \%$ in $2011^{3,4}$.

PTB is the leading cause of neonatal mortality in non-anomalous newborns ${ }^{1,3,5,6}$. It is also associated with a broad spectrum of lifelong morbidity in surviving preterm infants, including neuro-developmental delay, cerebral palsy, blindness, deafness, and chronic lung disease ${ }^{7-9}$.

\section{Definition of spontaneous preterm birth}

Some PTBs are iatrogenic and can be attributed to obstetric intervention aimed at reducing maternal and/or fetal risk. The remaining PTBs are known as spontaneous PTB (SPTB) and are the focus of research efforts to identify genetic and environmental risk factors. Although SPTB is a pressing health issue, the incomplete understanding of its biology has inhibited development of effective prevention and treatment strategies.

\section{Genetics of spontaneous preterm birth}

The etiology of SPTB is complex and multifactorial ${ }^{9-12}$, although genetic factors are important contributors ${ }^{9-14}$. In addition, PTB prevalence varies among different population groups ${ }^{15-19}$. African-American ancestry is consistently associated with an increased PTB risk, even after adjusting for epidemiologic risk factors, such as income, education, lack of prenatal care, and other socioeconomic factors ${ }^{10,20,21}$.

A candidate gene approach has identified polymorphisms in genes that encode the progesterone receptor, tumor necrosis factor alpha, interleukins 4, 6, and 10, and mannose-binding lectin ${ }^{22-33}$, that are mildly to modestly associated with SPTB. However, results have been inconsistent ${ }^{29,34-36}$.

Our genome-wide approach for spontaneous preterm birth Here, we employed an unbiased, genome-wide approach to search for possible candidate genes associated with SPTB. Genome-wide association studies (GWAS), or whole genome association studies, are a commonly used genetic approach to study a disease or a trait. GWAS compares thousands or even millions of common genetic markers, mainly single nucleotide polymorphisms (SNPs), across individuals with a disease or trait status. There are 1,688 publications identifying 11,299 SNPs that are significant for diseases or traits in 17 different categories ${ }^{37,38}$. We obtained the SPTB phenotype and genotype data deposited in the National Center for Biotechnology Information (NCBI) Genotypes and Phenotypes Database $(\mathrm{dbGaP})^{39,40}$, study accession phs000103.v1.p1, to perform a GWAS to explore genetic variants associated with SPTB.

\section{Materials and methods}

Data application and approval

We applied to and received approval from $\mathrm{dbGaP}^{39,40}$ for access to a dataset for SPTB phenotype and genotype (study accession phs000103.v1.p1). We followed the Data Use Certification Agreement we signed during the application.

To access the data, one must apply and agree to the dbGAP terms of usage. A detailed instructions and procedures for application can be obtained at https://dbgap.ncbi.nlm.nih.gov/.

\section{Data content}

This dataset contains participants collected by the Danish National Birth Cohort (DNBC) ${ }^{41}$. DNBC is a prospective cohort that enrolled more than 100,000 pregnant women in the first trimester, before most adverse outcomes occurred, and therefore is free from sampling or collection bias. In this dataset, there are approximately 1000 preterm births and 1000 term births as controls. These study subjects were collected from 1997 to 2003. All are singleton gestations. Each birth has records of mother-child pairs. With the exception of 24 children with one or two grandparents from other Nordic countries, all other children in the dataset had parents and all four grandparents born in Denmark.

The case (preterm) group contains births delivered before 37 gestational weeks. The control (term) group contains births delivered at approximately 40 weeks' gestation. In both preterm and term groups, children born with any recognized congenital or genetic abnormality were excluded. Pregnancies with maternal conditions known to be associated with PTB, iatrogenic or spontaneous (placenta previa, placental abruption, hydramnios, isoimmunization, placental insufficiency, pre-eclampsia/eclampsia), were also excluded by DNBC.

The blood sample (buffy coat) was collected for each mother-child pair. Their whole genomes were genotyped on the Illumina Human660WQuad_v1_A platform (Illumina, Inc., San Diego, California, USA), which contains more than 500,000 markers. Genotyping was performed by the Johns Hopkins University Center for Inherited Disease Research (Baltimore, Maryland, USA). Further data cleaning and harmonization were done at the GENEVA Coordinating Center at the University of Washington (Seattle, Washington, USA).

\section{Quality control}

In this study, we focused only on fetal genomes for further analysis. Individuals with missing genotypes greater than $3 \%$ were filtered out. In addition, individuals with a heterozygosity rate deviating more than 3 standard deviations were also excluded from further analysis $^{42}$. After per-individual quality control, we also performed per-SNP filtering. The SNPs that had missing genotypes greater than $3 \%$ were excluded ${ }^{42}$. Those having significantly different genotype missing rate between the case and control groups were also eliminated. A conservative cut-off with $\mathrm{p}<1 \times 10^{-5}$ was applied $^{42}$. We also excluded SNPs that significantly deviated from Hardy-Weinberg equilibrium in the control group - those with $\mathrm{p}<1 \times 10^{-5}$ were filtered out ${ }^{42,43}$.

\section{Data analysis}

After data quality control, we performed GWAS for the fetal genomes on 22 autosomal chromosomes using the PLINK software package $\mathrm{v} 1.07^{44}$ (http://pngu.mgh.harvard.edu/purcell/plink/). The 
level of genome-wide significance was set at $9.18 \times 10^{-8}$, corresponding to Bonferroni correction for 544,675 multiple independent tests.

Quantile-quantile (QQ) plot was made using STATA Statistical Software, Release $12^{45}$. Manhattan plots were generated using Haploview ${ }^{46}$.

\section{Results}

\section{Data overview}

We started with a dataset comprised of 1,900 children. There were 31 children having a missing genotype rate greater than $3 \%$. The average heterozygosity was 0.3238 , with standard deviation of 0.0059 . There were also 31 children having heterozygosity that deviated more than 3 standard deviations. In fact, there was considerable overlap when applying these two filtering criteria (Figure 1) - 26 individuals were identified by both exclusion criteria. During per-individual quality control, a total of 36 individuals were excluded, resulting in 1864 individuals. However, 66 of them had a missing phenotype, yielding a final total of 849 cases and 949 controls (Table 1).

Among the 560,768 markers, there were 1,933 SNPs that exceeded the missing rate threshold of 3\%. There were 367 SNPs that had a significantly different missing rate between the case group and control group ( $\mathrm{P}$ value $<1 \times 10^{-5}$ ). Further, 885 SNPs significantly deviated from Hardy-Weinberg equilibrium in the control group
( $\mathrm{P}$ value $<1 \times 10^{-5}$ ). These three criteria also identified some overlapping SNPs; a total of 2,670 SNPs were excluded using all criteria. These quality control steps left 558,098 SNPs remaining in the dataset. Of these SNPs, 544,675 of them are located on 22 autosomes, and were included in the analysis (Table 1).

\section{Allelic test}

We carried out GWAS for these 1,798 individuals, of which 849 are SPTB cases and 949 are term controls, over 544,675 SNPs on 22 autosomal chromosomes. An allelic test was first carried out, and no SNPs reached genome-wide significance after Bonferroni correction for multiple testing (Manhattan plot (Figure 2) and QQ plot (Figure 3)).

\section{Other genetic models}

We then performed GWAS with different genetic models. We tested three classical Mendelian inheritance models here. The recessive model assumes that carrying two variant alleles is required to present a different phenotype; while in the dominant model, one variant allele is sufficient to present a different phenotype as carrying two variant alleles. The additive model assumes the heterozygotes present an intermediate phenotype between the two homozygotes and thus consider the three genotypes separately. The Manhattan plot for the additive model (Figure 4), dominant model (Figure 5), and recessive model (Figure 6) are shown. The dominant or recessive models refer to the action of the minor allele. Within these

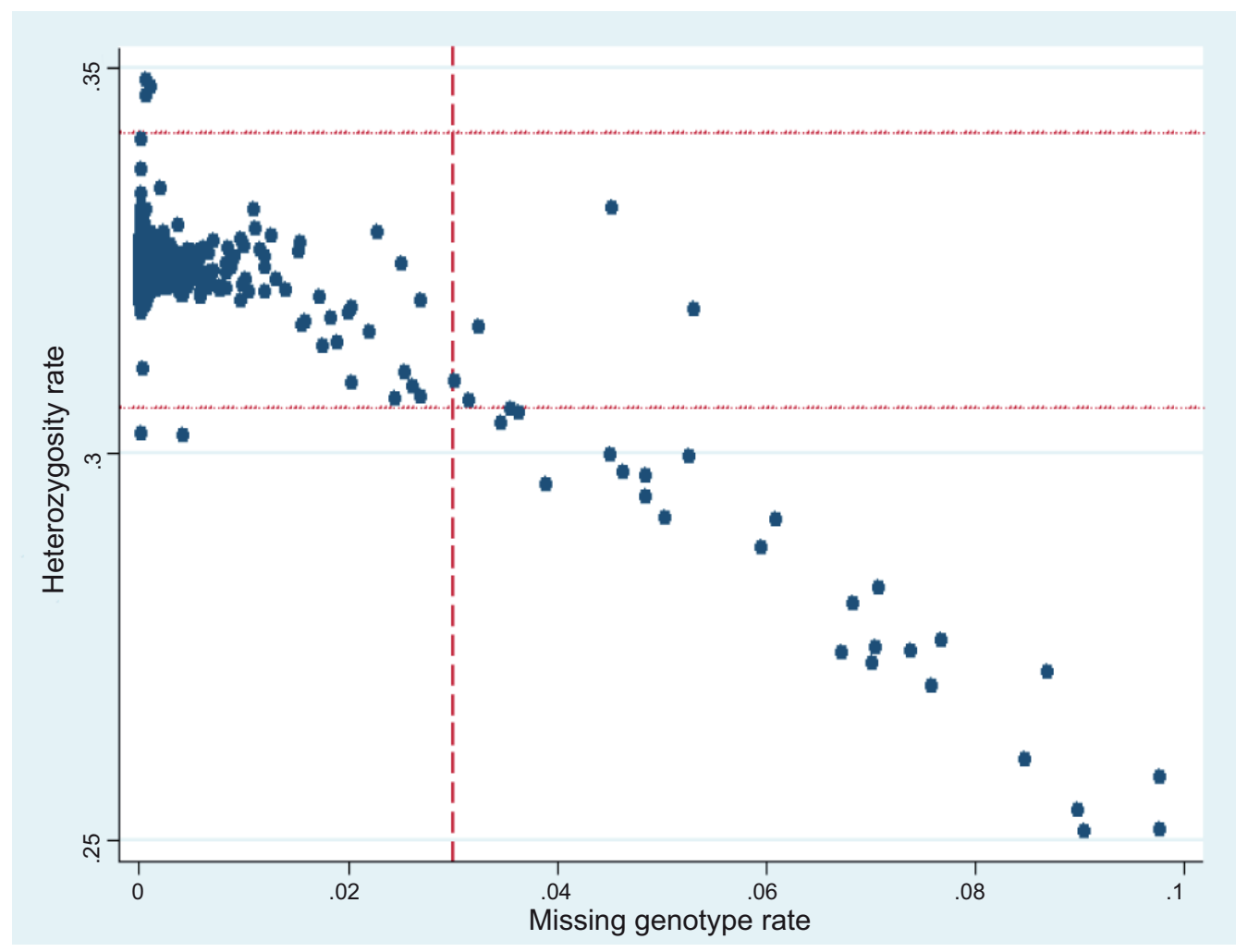

Figure 1. Per-individual quality control. The $X$ axis is the missing genotype rate for each individual. The $Y$ axis is the heterozygosity rate for each individual. Each dot represents a person. The vertical dash line is the cut-off for per-individual missing rate: $3 \%$. Individuals with missing rate greater than $3 \%$ are excluded. The two horizontal dot lines represent the mean heterozygosity \pm 3 standard deviations. People with heterozygosity deviate above 3 standard deviations are also excluded. The two criteria overlap largely at the right lower part of the graph. 


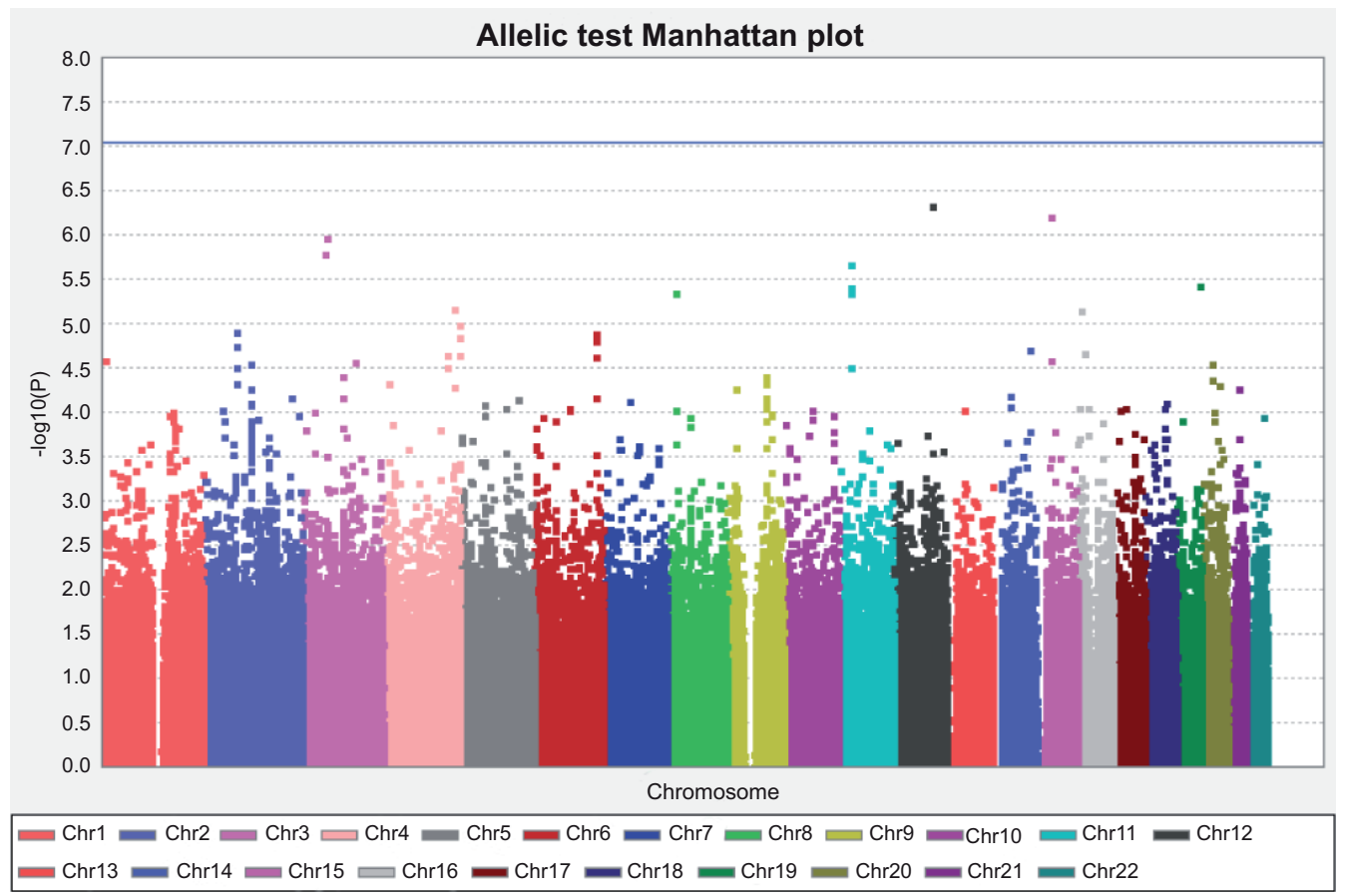

Figure 2. Manhattan plot for allelic test. The $X$ axis is the position of each SNP grouped by different chromosomes, and presented with different colors. The $Y$ axis is the $P$ value for each test for each SNP, in -log 10 scale. The horizontal blue line indicated the threshold of genome-wide significance after Bonferroni correction. The threshold is at 7.04, which corresponds to -log10 (0.05/544,675) for 544,675 independent tests. No SNP reached genome-wide significance.

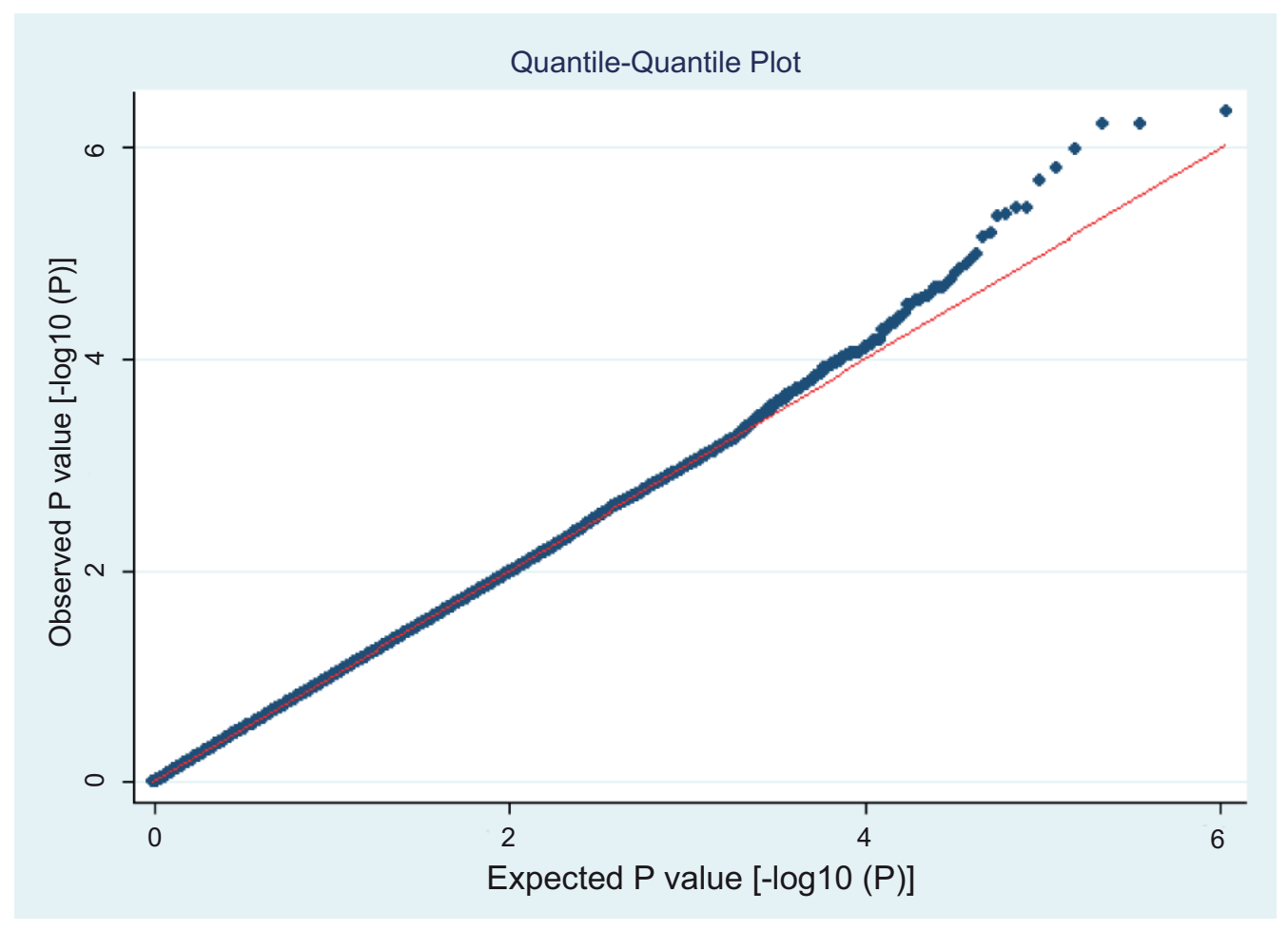

Figure 3. QQ plot for allelic test. The $X$ axis indicated the expected $P$ value, in -log10 scale. The $Y$ axis indicated the observed $P$ value from allelic test, also in - $\log 10$ scale. The red diagonal line is the line of $Y=X$, where observed equals expected. The genome-wide significance threshold for $-\log 10(\mathrm{P})$ scale is at 7.04 , which corresponds to $-\log 10(0.05 / 544,675)$ for 544,675 independent tests. No SNP reached genome-wide significance. 


\section{Table 1. Number of participants and markers in the dataset.}

\begin{tabular}{|ll|}
\hline I. Participants & (Individuals) \\
\hline Original dataset & $\mathbf{1 9 0 0}$ \\
\hline $\begin{array}{l}\text { Per-individual } \\
\text { quality control exclusion }\end{array}$ & $\mathbf{3 6}$ \\
\hline Missing genotype rate > 3\% & $\mathbf{3 1}$ \\
\hline Heterozygosity > 3 sd & $\mathbf{3 1}$ \\
\hline Missing phenotype & $\mathbf{6 6}$ \\
\hline Remained for analysis & $\mathbf{1 , 7 9 8}$ \\
\hline $\begin{array}{l}\text { II. Markers } \\
\text { Original dataset }\end{array}$ & $\mathbf{( S N P s )}$ \\
\hline $\begin{array}{l}\text { Per-marker } \\
\text { quality control exclusion }\end{array}$ & $\mathbf{2 , 6 7 0}$ \\
\hline $\begin{array}{l}\text { Missing genotype rate > } 3 \% \\
\text { Missing genotype rate }\end{array}$ & $\mathbf{1 , 9 3 3}$ \\
$\begin{array}{l}\text { significantly different } \\
\text { between case and control }\end{array}$ & $\mathbf{3 6 7}$ \\
\hline $\begin{array}{l}\text { Significantly deviate from } \\
\text { Hardy-Weinberg } \\
\text { equilibrium in control group }\end{array}$ & $\mathbf{8 8 5}$ \\
\hline Not on autosomes & $\mathbf{1 3 , 4 2 3}$ \\
\hline Remained for analysis & $\mathbf{5 4 4 , 6 7 5}$ \\
\hline
\end{tabular}

sd: standard deviations. genetic models, no SNP reached genome-wide significance after Bonferroni correction for multiple testing.

\section{Discussion}

Here we describe a negative result for associations between SPTB and genetic polymorphisms of 22 autosomal chromosomes in a homogeneous European population. Myking et al. reported a GWAS focusing on the $\mathrm{X}$ chromosome ${ }^{47}$ and they incorporated Danish cases and controls from $\mathrm{DNBC}^{41,47}$, in addition to participants enrolled from the Norwegian Mother and Child Cohort Study $(\mathrm{MoBa})^{48}$.Nevertheless, with a larger sample size $(\mathrm{DNBC}+\mathrm{MoBa})$, and fewer independent tests limited to the markers on $\mathrm{X}$ chromosomes, no SNP reached genome-wide significance after Bonferroni correction $^{47}$.

One way to decrease the probability of a negative result is to increase the sample size, either by recruiting more cases and controls directly, or by combining different studies and conducting a meta-analysis ${ }^{49,50}$. Instead of sequencing thousands or millions of sporadic cases plus controls, another approach is to study SPTB using a family-based design - i.e., identify high-risk pedigrees in which a genetic mutation is more likely to be present in multiple individuals. Pedigree studies have the additional advantage of reduced phenotypic heterogeneity $^{49}$. Several loci associated with SPTB have been identified by using family-based linkage studies ${ }^{51,52}$.

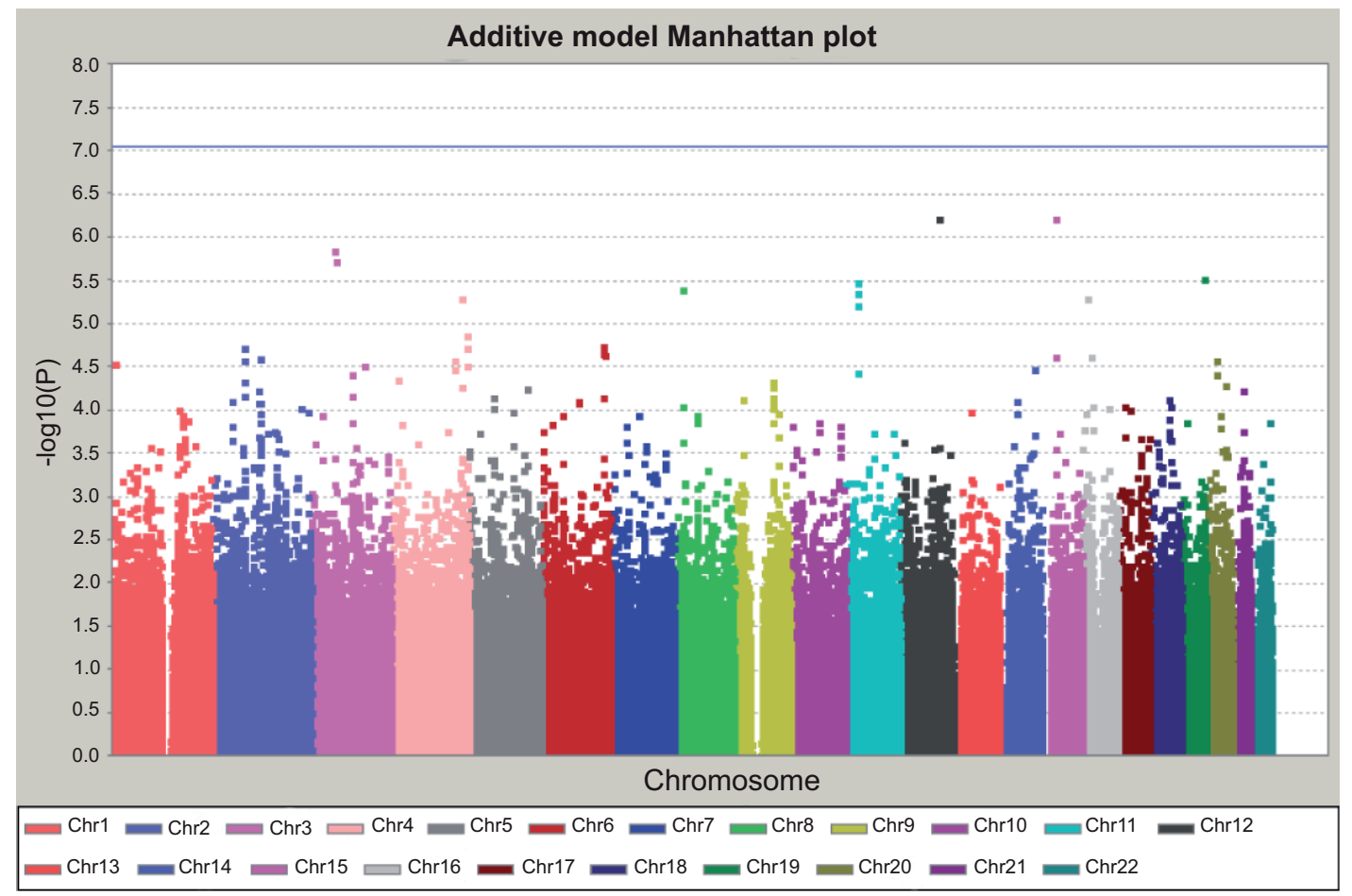

Figure 4. Manhattan plot for additive model. The $X$ axis is the position of each SNP grouped by different chromosomes, and presented with different colors. The $\mathrm{Y}$ axis is the $\mathrm{P}$ value for each test for each SNP, in -log10 scale. The horizontal blue line indicated the threshold of genome-wide significance after Bonferroni correction. The threshold is at 7.04 , which corresponds to $-\log 10(0.05 / 544,675)$ for 544,675 independent tests. No SNP reached genome-wide significance. 


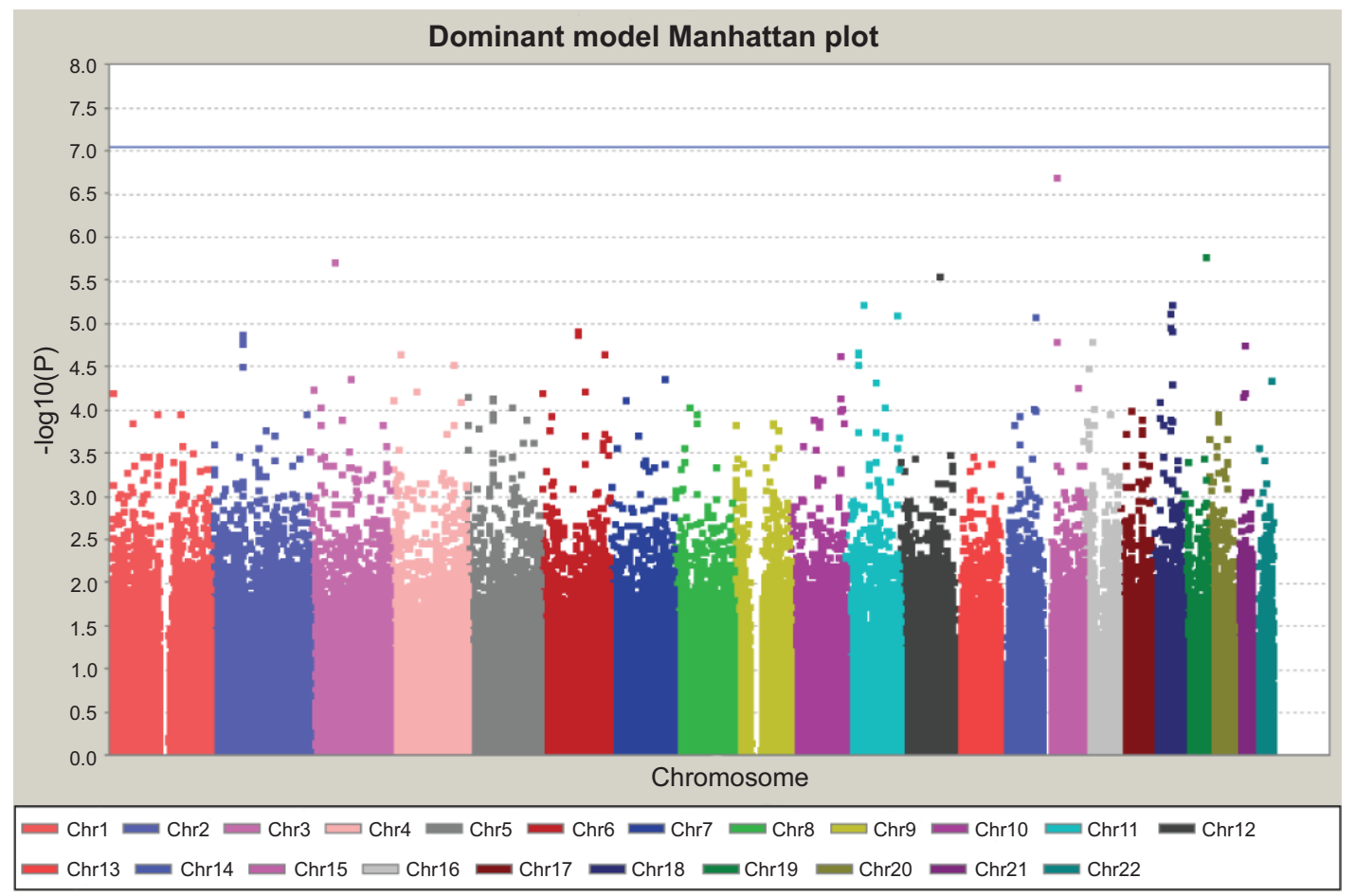

Figure 5. Manhattan plot for dominant model. This is the GWAS result assuming the dominant action of minor alleles. The $Y$ axis is the $P$ value for each test for each SNP, in -log10 scale. The horizontal blue line indicated the threshold of genome-wide significance after Bonferroni correction. The threshold is at 7.04 , which corresponds to - $\log 10(0.05 / 544,675)$ for 544,675 independent tests. No SNP reached genome-wide significance.

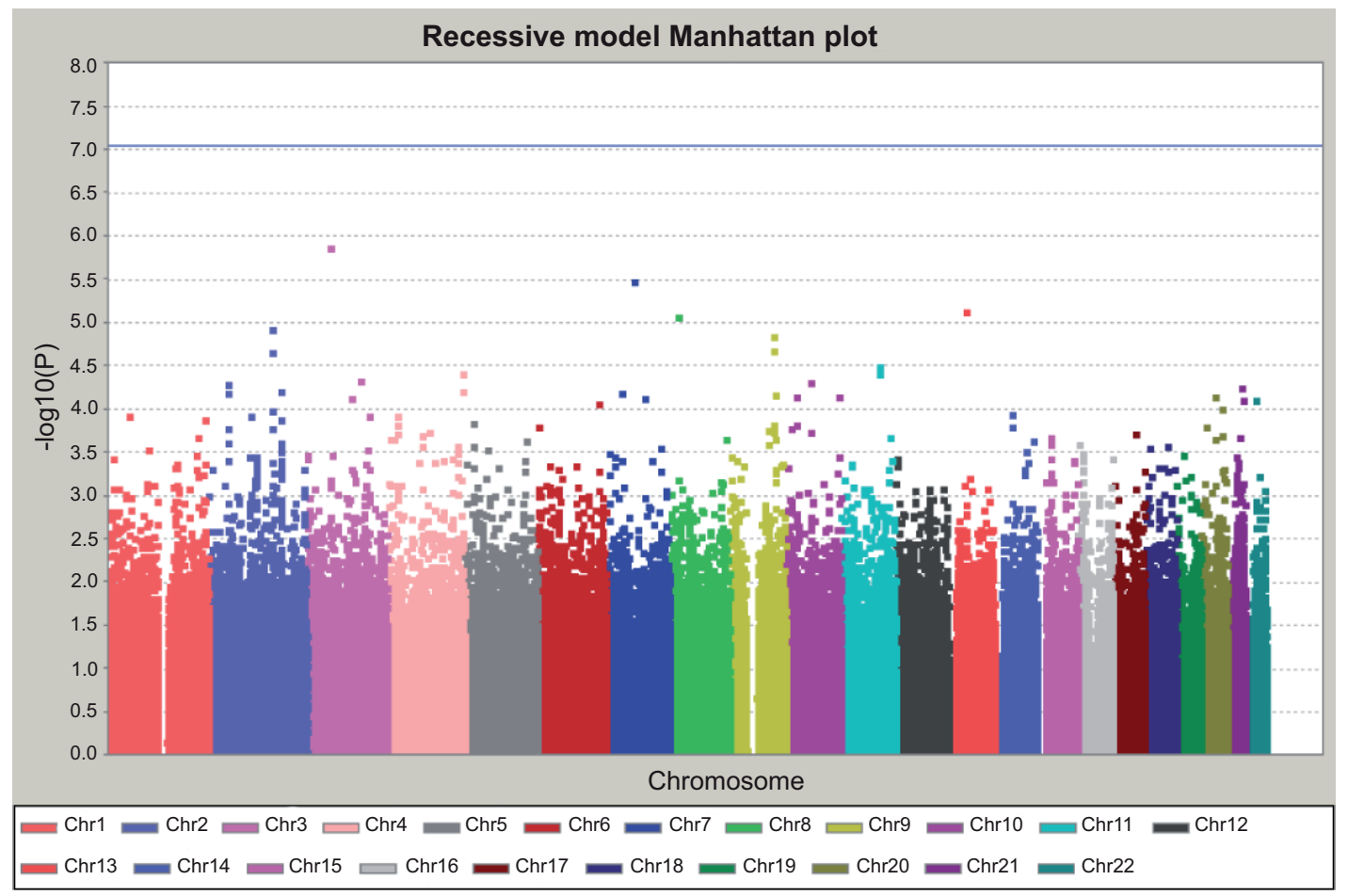

Figure 6. Manhattan plot for recessive model. This is the GWAS result assuming the recessive action of minor alleles. The $Y$ axis is the $P$ value for each test for each SNP, in -log10 scale. The horizontal blue line indicated the threshold of genome-wide significance after Bonferroni correction. The threshold is at 7.04 , which corresponds to - $\log 10(0.05 / 544,675)$ for 544,675 independent tests. No SNP reached genome-wide significance. 
Another approach is to employ whole genome or whole exome sequencing. This will help to identify rare genetic variants with potentially larger effect sizes.

Another approach that may increase statistical power is to analyze the SPTB phenotype as a quantitative trait instead of a dichotomous one. The distribution of gestational age in the population is approximately normal ${ }^{53}$. Therefore, to analyze SPTB as a quantitative trait (i.e., gestational age), samples should be drawn randomly from the population of newborns.

\section{Conclusion}

We found no evidence of genetic association with SPTB in Danish population using an unbiased genome-wide approach. A familybased design in a high risk pedigree, and whole genome or exome sequencing, may yield higher detection rates of both common and rare variants associated with SPTB.

\section{Author contributions}

WW conceived of and designed the study. EASC, TAM, MSE, $\mathrm{MV}$, and LBJ provided input to the study design. WW and LBJ applied for data access and conducted the analysis. WW drafted the manuscript. EASC, TAM, MSE, MV, and LBJ provided critical review. All authors read and approved the final manuscript.

\section{Competing interests}

No competing interests were disclosed.

\section{Grant information}

EASC is supported by National Institutes of Health, National Institute of Child Health and Human Development (K23HD061910). We would like to acknowledge DNBC, dbGAP, and NCBI for depositing and hosting the phenotype and genotype data.

The funders had no role in study design, data collection and analysis, decision to publish, or preparation of the manuscript.

\section{Acknowledgements}

We would like to acknowledge DNBC, dbGAP, and NCBI for depositing and hosting the phenotype and genotype data. We would like to thank Robert Weiss from Department of Human Genetics, University of Utah, for his detailed consultations for data analysis. We would also like to thank Isabella Johnsen and June Blackburn from University of Utah for their assistances during our application for dbGAP data access.
1. Reich ES: Pre-term births on the rise. Nature. 2012; 485(7396): 20 PubMed Abstract | Publisher Full Text

2. Blencowe $\mathrm{H}$, Cousens $\mathrm{S}$, Oestergaard $\mathrm{MZ}$, et al:: National, regional, and worldwide estimates of preterm birth rates in the year $\mathbf{2 0 1 0}$ with time trends since 1990 for selected countries: a systematic analysis and implications. Lancet. 2012; 379(9832): 2162-72. PubMed Abstract | Publisher Full Tex

3. Hamilton BE, Hoyert DL, Martin JA, et al:: Annual summary of vital statistics: 2010-2011. Pediatrics. 2013; 131(3): 548-58.

PubMed Abstract | Publisher Full Text

4. Raju TN: Epidemiology of late preterm (near-term) births. Clin Perinatol. 2006; 33(4): 751-763. abstract vii. PubMed Abstract | Publisher Full Text

5. Liu L, Johnson HL, Cousens S, et al.: Global, regional, and national causes of child mortality: an updated systematic analysis for $\mathbf{2 0 1 0}$ with time trends since 2000. Lancet. 2012; 379(9832): 2151-61. PubMed Abstract | Publisher Full Text

6. Mathew T, MacDorman M: Infant Mortality Statistics from the $\mathbf{2 0 0 3}$ Period Linked Birth/Infant Death Data Set. Natl Vital Stat Rep. 2006; 54(16): 1-29. PubMed Abstract

7. Damus K: Prevention of preterm birth: a renewed national priority. Curr Opin Obstet Gynecol. 2008; 20(6): 590-6. PubMed Abstract | Publisher Full Text

8. Wood NS, Marlow N, Costeloe K, et al.: Neurologic and developmental disability after extremely preterm birth. EPICure Study Group. N Engl J Med. 2000; 343(6): 378-84.

PubMed Abstract | Publisher Full Text

9. Muglia LJ, Katz M: The enigma of spontaneous preterm birth. N Engl J Med. 2010; 362(6): 529-35. PubMed Abstract | Publisher Full Text

10. Kistka ZA, Palomar L, Lee KA, et al.: Racial disparity in the frequency of recurrence of preterm birth. Am J Obstet Gynecol. 2007; 196(2): 131.e1-6. PubMed Abstract | Publisher Full Text

11. Collins JW Jr, David RJ, Handler A, et al:: Very low birthweight in African American infants: the role of maternal exposure to interpersonal racial discrimination. Am J Public Health. 2004; 94(12): 2132-8. PubMed Abstract | Publisher Full Text | Free Full Text
12. Goldenberg RL, Culhane JF, lams JD, et al:: Epidemiology and causes of preterm birth. Lancet. 2008; 371(9606): 75-84. PubMed Abstract | Publisher Full Text

13. Clausson B, Lichtenstein $P$, Cnattingius S: Genetic influence on birthweight and gestational length determined by studies in offspring of twins. BJOG. 2000; 107(3): 375-81. PubMed Abstract | Publisher Full Text

14. Treloar SA, Macones GA, Mitchell LE, et al:: Genetic influences on premature parturition in an Australian twin sample. Twin Res. 2000; 3(2): 80-2. PubMed Abstract | Publisher Full Text

15. Esplin MS, O'Brien E, Fraser A, et al.: Estimating recurrence of spontaneous preterm delivery. Obstet Gynecol. 2008; 112(3): 516-23. PubMed Abstract | Publisher Full Text

16. Adams MM, Elam-Evans LD, Wilson HG, et al:: Rates of and factors associated with recurrence of preterm delivery. JAMA. 2000; 283(12): 1591-6. PubMed Abstract | Publisher Full Text

17. Bakketeig LS, Hoffman HJ, Harley EE: The tendency to repeat gestational age and birth weight in successive births. Am J Obstet Gynecol. 1979; 135(8): 1086-103. PubMed Abstract

18. Porter TF, Fraser AM, Hunter $\mathrm{CY}$, et al.: The risk of preterm birth across generations. Obstet Gynecol. 1997; 90(1): 63-7. PubMed Abstract | Publisher Full Text

19. Winkvist A, Mogren I, Högberg U: Familial patterns in birth characteristics: impact on individual and population risks. Int J Epidemiol. 1998; 27(2): 248-54. PubMed Abstract | Publisher Full Text

20. Manuck TA, Lai $Y$, Meis PJ, et al.: Admixture mapping to identify spontaneous preterm birth susceptibility loci in African Americans. Obstet Gynecol. 2011; 117(5): 1078-84. PubMed Abstract | Publisher Full Text | Free Full Text

21. Tsai HJ, Hong $X$, Chen J, et al.: Role of African ancestry and gene-environment interactions in predicting preterm birth. Obstet Gynecol. 2011; 118(5): 1081-9. PubMed Abstract | Publisher Full Text | Free Full Text

22. Ehn NL, Cooper ME, Orr K, et al.: Evaluation of fetal and maternal genetic variation in the progesterone receptor gene for contributions to preterm birth. Pediatr Res. 2007; 62(5): 630-5. PubMed Abstract | Publisher Full Text | Free Full Text 
23. Aidoo M, McElroy PD, Kolczak MS, et al:: Tumor necrosis factor-alpha promoter variant 2 (TNF2) is associated with pre-term delivery, infant mortality, and malaria morbidity in western Kenya: Asembo Bay Cohort Project IX. Genet Epidemiol. 2001; 21(3): 201-11.

PubMed Abstract | Publisher Full Text

24. Chen D, Hu Y, Wu B, et al:: Tumor necrosis factor-alpha gene G308A polymorphism is associated with the risk of preterm delivery. Beijing Da Xue Xue Bao. 2003; 35(4): 377-81.

PubMed Abstract

25. Simhan HN, Krohn MA, Roberts JM, et al:: Interleukin-6 promoter-174 polymorphism and spontaneous preterm birth. Am J Obstet Gynecol. 2003; 189(4): 915-8. PubMed Abstract | Publisher Full Text

26. Moore S, Ide M, Randhawa M, et al:: An investigation into the association among preterm birth, cytokine gene polymorphisms and periodontal disease. BJOG. 2004; 111(2): 125-32.

PubMed Abstract | Publisher Full Text

27. Kalish RB, Vardhana S, Gupta M, et al.: Interleukin-4 and -10 gene polymorphisms and spontaneous preterm birth in multifetal gestations. Am J Obstet Gynecol. 2004; 190(3): 702-6.

PubMed Abstract | Publisher Full Text

28. Macones GA, Parry S, Elkousy M, et al: A polymorphism in the promoter region of TNF and bacterial vaginosis: preliminary evidence of gene-environment interaction in the etiology of spontaneous preterm birth. Am J Obstet Gynecol. 2004; 190(6): 1504-1508. discussion 3A. PubMed Abstract | Publisher Full Text

29. Amory $\mathrm{JH}$, Adams KM, Lin MT, et al.: Adverse outcomes after preterm labor are associated with tumor necrosis factor-alpha polymorphism -863 , but not -308 , in mother-infant pairs. Am J Obstet Gynecol. 2004; 191(4): 1362-7. PubMed Abstract | Publisher Full Text

30. Annells MF, Hart PH, Mullighan CG, et al: Interleukins-1, $-4,-6,-10$, tumor necrosis factor, transforming growth factor-beta, FAS and mannose-binding protein $\mathrm{C}$ gene polymorphisms in Australian women: Risk of preterm birth. Am J Obstet Gynecol. 2004; 191(6): 2056-67. PubMed Abstract | Publisher Full Text

31. Härtel $C$, Finas $D$, Ahrens $P$, et al:: Polymorphisms of genes involved in innate immunity: association with preterm delivery. Mol Hum Reprod. 2004; 10(12): 911-5

PubMed Abstract | Publisher Full Text

32. Engel SAM, Erichsen HC, Savitz DA, et al: Risk of spontaneous preterm birth is associated with common proinflammatory cytokine polymorphisms. Epidemiology. 2005; 16(4): 469-77. PubMed Abstract | Publisher Full Text

33. Wu W, Clark EAS, Stoddard GJ, et al: Effect of interleukin-6 polymorphism on risk of preterm birth within population strata: a meta- analysis. BMC Genet. 2013; 14: 30 .

PubMed Abstract | Publisher Full Text | Free Full Text

34. Diaz-Cueto L, Dominguez-Lopez P, Cantillo-Cabarcas J, et al.: Progesterone receptor gene polymorphisms are not associated with preterm birth in a Hispanic population. Int J Gynaecol Obstet. 2008; 103(2): 153-7. PubMed Abstract | Publisher Full Text

35. Guoyang Luo, Morgan T, Bahtiyar MO, et al:: Single nucleotide polymorphisms in the human progesterone receptor gene and spontaneous preterm birth. Reprod Sci. 2008; 15(2): 147-55

PubMed Abstract | Publisher Full Text

36. Plunkett J, Muglia LJ: Genetic contributions to preterm birth: Implications from epidemiological and genetic association studies. Ann Med. 2008; 40(3): 167-79.

PubMed Abstract | Publisher Full Text
37. Hindorff LA, Sethupathy $P$, Junkins HA, et al.: Potential etiologic and functional implications of genome-wide association loci for human diseases and traits. Proc Natl Acad Sci U S A. 2009; 106(23): 9362-7.

PubMed Abstract | Publisher Full Text | Free Full Text

38. Hindorff L, MacArthur J, Morales J, et al:: Catalog of Published Genome-Wide Association Studies [Internet]. [cited $2013 \mathrm{Sep} 2$ ] Reference Source

39. Mailman MD, Feolo M, Jin Y, et al:: The NCBI dbGaP database of genotypes and phenotypes. Nat Genet. 2007; 39(10): 1181-6.

PubMed Abstract | Publisher Full Text | Free Full Text

40. Database of Genotypes and Phenotypes (dbGaP). Bethesda (MD): National Center for Biotechnology Information, National Library of Medicine. [Internet]. Reference Source

41. Olsen J, Melbye M, Olsen SF, et al.: The Danish National Birth Cohort--its background, structure and aim. Scand J Public Health. 2001; 29(4): 300-7. PubMed Abstract | Publisher Full Text

42. Anderson $\mathrm{CA}$, Pettersson $\mathrm{FH}$, Clarke GM, et al.: Data quality control in genetic case-control association studies. Nat Protoc. 2010; 5(9): 1564-73. PubMed Abstract | Publisher Full Text | Free Full Text

43. Balding DJ: A tutorial on statistical methods for population association studies. Nat Rev Genet. 2006; 7(10): 781-91. PubMed Abstract | Publisher Full Text

44. Purcell S, Neale B, Todd-Brown K, et al:: PLINK: a tool set for whole-genome association and population-based linkage analyses. Am J Hum Genet. 2007; 81(3): 559-75.

PubMed Abstract | Publisher Full Text | Free Full Text

45. Stata Corp. LP. STATA Statistical Software: Release 12. College Station, TX; 2011.

46. Barrett JC, Fry B, Maller J, et al.: Haploview: analysis and visualization of LD and haplotype maps. Bioinformatics. 2005; 21(2): 263-5.

PubMed Abstract | Publisher Full Text

47. Myking S, Boyd HA, Myhre R, et al.: X- chromosomal maternal and fetal SNPs and the risk of spontaneous preterm delivery in a Danish/Norwegian genome-wide association study. PLOS One. 2013; 8(4): e61781. PubMed Abstract | Publisher Full Text | Free Full Text

48. Magnus P, Irgens LM, Haug K, et al:: Cohort profile: the Norwegian Mother and Child Cohort Study (MoBa). Int J Epidemiol. 2006; 35(5): 1146-50. PubMed Abstract | Publisher Full Text

49. Ioannidis JP, Thomas G, Daly MJ: Validating, augmenting and refining genome-wide association signals. Nat Rev Genet. 2009; 10(5): 318-29. PubMed Abstract | Publisher Full Text

50. Ehret GB, Munroe PB, Rice KM, et al:: Genetic variants in novel pathways influence blood pressure and cardiovascular disease risk. International Consortium for Blood Pressure Genome-Wide Association Studies. Nature. 2011; 478(7367): 103-9. PubMed Abstract | Publisher Full Text | Free Full Text

51. Haataja R, Karjalainen MK, Luukkonen A, et al:: Mapping a new spontaneous preterm birth susceptibility gene, IGF1R, using linkage, haplotype sharing, and association analysis. PLoS Genet. 2011; 7(2): e1001293. PubMed Abstract | Publisher Full Text | Free Full Text

52. Bream EN, Leppellere $\mathrm{CR}$, Cooper ME, et al: Candidate gene linkage approach to identify DNA variants that predispose to preterm birth. Pediatr Res. 2013; 73(2): 135-41.

PubMed Abstract | Publisher Full Text | Free Full Text

53. Kieler $\mathrm{H}$, Axelsson $\mathrm{O}$, Nilsson $\mathrm{S}$, et al:: The length of human pregnancy as calculated by ultrasonographic measurement of the fetal biparietal diameter. Ultrasound Obstet Gynecol. 1995; 6(5): 353-7. PubMed Abstract | Publisher Full Text 


\section{Open Peer Review}

\section{Current Peer Review Status: ? ?}

\section{Version 1}

Reviewer Report 24 November 2014

https://doi.org/10.5256/f1000research.2631.r6795

(C) 2014 Olson D et al. This is an open access peer review report distributed under the terms of the Creative Commons Attribution License, which permits unrestricted use, distribution, and reproduction in any medium, provided the original work is properly cited.

\section{David Olson}

Department of Obstetrics and Gynecology, University of Alberta, Edmonton, AB, Canada Scott Williams

Department of Genetics, Institute of Quantitative Biomedical Sciences, Geisel School of Medicine, Dartmouth College, Hanover, NH, USA

\section{From Scott Williams:}

I have now read the paper and as it stands it is ok. I would however recommend several things that may improve it:

1. State that the data generally suggests that most effects are maternal so that this may be a hard task.

2. Note whether any of the candidate genes that have even nominal data fall in regions of statistical significance. Although not proof positive such findings would support an association - albeit not novel.

3. I always like to ask if the cases are in HWE as well as the controls as there are several papers I could cite - including some of our own that indicate this is a good way to detect effects.

4. Lastly, I am concerned that their bonferonni correction is too conservative as the $\sim 550,000$ are not all independent. We have paper in press on this point.

That said nothing the authors have done is incorrect - only what I would consider to be a too limited exploration of the data. And since this type of study is by nature exploratory I would focus on lowering type 2 errors as opposed to type 1 (e.g., bonferonni corrections).

\section{From David Olson:}

Preterm birth is a very complex and heterogeneous problem; there are many causes, and these can vary according to gestational age. I would have expected the outcomes observed (no significant SNPs) because the authors did not stratify their preterm birth subjects into 
homogeneous groups. They should have separated single fetus pregnancies from multiple-fetus pregnancies, excluded those with other pre-disposing problems such as pre-eclampsia, preterm premature rupture of membranes, incompetent cervix, etc., and they should have stratified according to age: $<28$ weeks gestational age, 28-30, 30-34 and 34-37. I would suggest they reanalyze their data according to such stratification in an attempt to create more homogeneous groups.

Competing Interests: No competing interests were disclosed.

We confirm that we have read this submission and believe that we have an appropriate level of expertise to confirm that it is of an acceptable scientific standard, however we have significant reservations, as outlined above.

Reviewer Report 06 February 2014

https://doi.org/10.5256/f1000research.2631.r3489

(C) 2014 Saad M. This is an open access peer review report distributed under the terms of the Creative Commons Attribution License, which permits unrestricted use, distribution, and reproduction in any medium, provided the original work is properly cited.

\section{Mohamad Saad}

Division of Medical Genetics, University of Washington, Seattle, WA, USA

In their paper, "A Genome-Wide Association Study of spontaneous preterm birth in a European population", the authors perform a GWAS on spontaneous preterm birth in a European population. The GWAS is based on 849 cases (preterm births) and 949 controls (term births), and use a dense genotyping panel that contains over 500,000 SNPs. The paper is nicely written and the analyses are well done. However, I have several issues that need to be taken care of. In its actual form, this paper lacks additional analyses. Below are my non-exhaustive comments:

1. In this study, no SNP reaches the genome-wide significance threshold. However, as we can see in the Manhattan plot (Figure 2), there are several suggestive signals, especially on chromosome 12,15 , and 3 . The authors should investigate these signals and try to find the nearby genes.

2. They perform four models and show the corresponding Manhattan plots. First, they do not explain the reason why they perform these four models. Second, the allelic test should give similar results to the additive model test. The authors do not compare between these models, at least for the most significant signals. Otherwise, these analyses seem to be redundant.

3. Providing the Manhattan plots is far from enough. We do not have the ability to see the most significant SNP names. In addition, they should mention if there was a performed GWAS for preterm birth, and if so, they should compare their results with what can be found in the literature. Moreover, they mention that there is an evidence of a candidate gene. They should say how this gene was discovered, and show their SNP results in this 
gene or its region. In addition, the might consider performing the haplotypic test in this gene or in the region of the most significant SNPs. They should present these results in informative tables.

4. In the introduction, the authors say that there are genetic factors that contribute to SPTB. It is important to mention the heritability estimates or the familial recurrence risk estimate (if there is any) for SPTB.

5. The authors talk about negative results in their GWAS. They should discuss why they did not discover any genome-wide significant SNP (lack of power?). They also need to discuss the weaknesses of this study, and what could be done in the future.

Competing Interests: No competing interests were disclosed.

I confirm that I have read this submission and believe that I have an appropriate level of expertise to confirm that it is of an acceptable scientific standard, however I have significant reservations, as outlined above.

The benefits of publishing with F1000Research:

- Your article is published within days, with no editorial bias

- You can publish traditional articles, null/negative results, case reports, data notes and more

- The peer review process is transparent and collaborative

- Your article is indexed in PubMed after passing peer review

- Dedicated customer support at every stage

For pre-submission enquiries, contact research@f1000.com 